\title{
Antiphospholipid Antibody Role in Acute Ischemic Stroke Patients with COVID-19: A Narrative Review
}

\author{
Arnaz Adisaputra, MD, Salsa Nurfadilla, MD and Andry Gonius, MD \\ Universitas Brawijaya. Veteran Street Malang City, Indonesia
}

\begin{abstract}
Antiphospholipid antibodies (aPL) are commonly found in humans after an infection. Its action can promote thrombosis via the activation of endothelial cells, platelets, and neutrophils. This autoantibody is the leading cause of antiphospholipid antibody syndrome (APS), characterized by widespread thrombosis in various vascular beds. COVID-19 also causes acute ischemic stroke (AIS) in the younger demographic, who previously was not considered a population at risk for AIS, which may be related to APS. This narrative review will discuss the role of aPL in COVID-19 patients who experienced AIS during infection.
\end{abstract}

Keywords: Antiphospholipid antibody, Acute Ischemic Stroke, COVID-19, Antiphospholipid antibody syndrome

\section{INTRODUCTION}

Coronavirus disease 2019 (COVID-19) is a novel contagious disease caused by a Coronaviridae family named severe acute respiratory syndrome coronavirus 2 (SARSCoV-2). ${ }^{1}$ By the beginning of 2021, there were 92 million cases found, with 1.9 million death cases worldwide. ${ }^{2}$

The SARS-CoV-2 virus infects the human body primarily via interaction with angiotensin-converting enzyme 2 (ACE2) in the human respiratory tract. A recent study found that SARS-CoV-2 can cause disease in other organs which express ACE2 receptors, such as the heart, kidney, gastrointestinal tract, male genitals, and blood vessels. ${ }^{3}$

Antiphospholipid antibody (aPL antibody) is an autoantibody that binds to phospholipids and phospholipidbinding protein. Its action can promote thrombosis via the activation of endothelial cells, platelets, and neutrophils. This autoantibody is the leading cause of antiphospholipid antibody syndrome (APS), characterized by widespread thrombosis in various vascular beds. ${ }^{4}$ Several reports found aPL antibody in COVID-19 patients. Guerra et al. reported that 12 of 21 severe COVID-19 patients tested positive for this antibody. ${ }^{5}$ A cohort study in New York found that $44 \%$ (30 out of 68 ) of patients who tested positive for aPL antibody also tested positive for COVID-19, compared to $22 \%$ (27 out of 118) COVID-19 negative group. Also, this study reported that 63\% (19 out of 30) patients in the COVID-19-positive and aPL antibody-positive group had experienced thrombosis events. ${ }^{6}$

One manifestation of COVID-19 is acute ischemic

Corresponding author: Arnaz Adisaputra, MD Universitas Brawijaya

Veteran Street, Malang City, Indonesia 65145

Email: arnazsaputra@gmail.com stroke (AIS). The incidence of AIS in COVID-19 is reported between 1 to $6 \%$. COVID-19 also causes AIS in 
the younger demographic, who previously was not considered a population at risk for AIS. A study in New York found a 7-fold increase of large vessel stroke in young people compared with the previous year. Other studies also found that the mean age of large vessel stroke patients who tested positive for COVID-19 is younger than that of large vessel stroke patients who tested negative for COVID-19 (59 years vs. 74 years). ${ }^{7}$ Currently, the pathophysiology of AIS in COVID-19 patients is not well established.

Nonetheless, several mechanisms of COVID-19induced-AIS have been proposed, such as hypercoagulability, vasculitis, new-onset atrial fibrillation, and direct infection by the SARS-CoV-2 virus. $^{8}$ It has been suggested that the AIS in COVID-19 is linked with the presence of aPL autoantibody. We conducted a thorough literature search to find articles and peer-reviewed journals related to possible interactions between COVID-19, AIS, and aPL autoantibody. This paper aims to give an update of current knowledge about aPL in COVID-19 patients who experienced AIS.

\section{AIS in COVID-19}

Several studies reported the occurrence of AIS in COVID-19 patients. A systematic review by Kiat-Tan et al. noted that 54 out of 4466 COVID-19 patients experienced AIS (1.2\% pooled incidence). This data was collected from five observational cohort studies. The mean severity score of AIS in COVID-19 patients was $19 \pm 8$, measured with NIHHS score. ${ }^{9}$ Another systematic review from Nannoni $e t$ al. found that the stroke incidence rate in COVID-19 patients was $1.4 \%$, of which $87.4 \%$ of stroke cases were ischemic type. This study also reported that compared to the stroke cases in non-COVID-19 patients, stroke in COVID-19 occurred at a younger age, had a higher National Institutes of Health Stroke Scale (NIHSS) score, and had higher mortality. ${ }^{10}$ These findings are in line with another systematic review conducted by Siow et al. The majority of strokes in COVID-19 patients were the ischemic type (an average of $82.8 \%$ from 27 studies). Large vessel ischemic stroke was the most common pattern found in this group of patients. ${ }^{11}$ Mortality rate in AIS patients tested positive for COVID-19 was nine times higher than COVID-19-negative AIS patients. ${ }^{12}$ In conclusion, AIS has already been recognized as one of the consequences of COVID-19 infection.

\section{aPL antibody in general}

Phospholipids are substances in the blood that are required for the blood to clot. ${ }^{13}$ A group of antibodies directed against phospholipid called Antiphospholipid antibodies (aPL). aPL can target the anionic and neutral phospholipids that form cellular membranes.$^{14}$ It consists of immunoglobulins $\operatorname{IgG}$, IgM, and IgA isotypes that target phospholipid (PL), PL-binding plasma proteins, or both. ${ }^{15}$ The most common aPL finding in Antiphospholipid syndrome is Lupus anticoagulants (LAC) and anticardiolipin antibodies $(\mathrm{aCL})$. LAC works by interfering with the phospholipid- dependent coagulation test, such as prothrombin time (PT) and activated partial thromboplastin time (aPTT). aCL has autoantigen properties towards negatively charged phospholipids such as cardiolipin, beta2-glycoprotein I, prothrombin, protein $\mathrm{C}$, etc. ${ }^{16}$ The other antibody that is frequently mentioned is anti-beta2-glycoprotein $\mathrm{I}\left(\mathrm{aB}_{2} \mathrm{GP} 1\right)$. This antibody has been proposed as the most critical factor in the development of thrombotic events in APS and could increase the specificity in the diagnosis of APS. ${ }^{16,17}$

\section{aPL antibody role in the vascular system}

aPL antibodies are commonly found in humans after an infection. A previous literature review found that this antibody is frequently present during an episode of viral infection, such as HIV, Hepatitis B, and Hepatitis C. ${ }^{18}$ This antibody usually disappears after the infection is over. Memory B-cells can produce this antibody, suggesting that antibodies may have a role in the typical human immune system. It might be acting like a "vacuum cleaner" that clears cellular debris in human blood circulation. aPL effect is instigated by its binding to phospholipid-binding protein $\beta 2$ glycoprotein I ( $\beta_{2}$ GPI). Then, this complex binds and removes any apoptotic cells, microparticles, and bacterial products present in blood circulation. Autoantibodies regulate this function against $\beta_{2}$ GPI naturally found in the human body. When these autoantibodies increase in titer and avidity, the physiological role of aPL- $\beta_{2}$ GPI is altered into a pathologic state. ${ }^{19}$ These pathologic complexes can form immune complexes and modify standard coagulation steps that could cause arterial or venous thrombosis. ${ }^{20}$

\section{aPL antibody findings in COVID-19-positive AIS patients}

There are several aPL that is usually used for classification criteria for antiphospholipid syndrome; aCL antibodies or $a \beta_{2}$ GPI antibodies, LAC, and anti-phosphatidylserine/ prothrombin autoantibodies (aPS/PT antibodies). ${ }^{4}$ Reports from several studies found that these antibodies can also be found in COVID-19-positive AIS patients. Beyrouti et al. reported a case series of 6 patients with COVID-19 and AIS, 5 of which tested positive for at least one aPL antibody mentioned above. ${ }^{21} \mathrm{~A}$ case report presented by Goldberg et al. noted a 64-year-old male with ischemic stroke in the right middle cerebral artery (MCA) and bilateral anterior cerebral artery (ACA). This patient was tested positive for IgM aCL antibody. ${ }^{22}$ One patient from a case series reported by Zayet et al. tested positive for $\operatorname{IgG}$ a $\beta_{2} \mathrm{GPI}$ antibody. ${ }^{23}$ Another case series from Zhang et al. mentioned that three patients with multiple cerebral infarctions tested positive for IgA aCL antibodies, IgG a $\beta_{2}$ GPI antibody, and IgA a $\beta_{2}$ GPI antibody. ${ }^{24}$ These studies showed that aPL antibody was prevalent among COVID-19-positive AIS patients. However, another study failed to find any aPL in these patients. Case reports from Deliwala et al., Viguier et al., and Gunaransekar et al. were unable to found these 
antibodies. $^{25-27}$ We reckon this difference arose because no standard aPL panel testing was available to test COVID19-positive AIS patients. Therefore, we postulated a need to establish which aPL antibody is directly associated with AIS in COVID-19 patients and develop a standard panel testing to find these aPL antibodies.

Table 1 below summarized AIS case reports in COVID19-positive patients and their reported aPL antibody findings. We also mentioned the patient's NIHSS score in this table. NIHSS is a score that measured stroke severity. It consists of 15 items of impairment scale, covering the level of consciousness, eye movements, the integrity of visual fields, facial movements, arm and leg muscle strength, sensation, coordination, language, speech, and neglect. It is ranged from 0 to 42 . A higher score indicates a more severe stroke. ${ }^{28}$

There are several postulation-related antibody antiphospholipid in COVID-19 patients. The first mechanism is the $\mathrm{S} 1$ and $\mathrm{S} 2$ subunit from $\mathrm{S}$ protein SARS-CoV-2 mimic phospholipid epitope, inducing $\mathrm{PL}$ antibodies. This process includes cell $\mathrm{T}$ mechanism antibody-dependent $\mathrm{T}$ cell which the virus triggers the immunologic response. This is confirmed with the occurrence of $\beta 2$-glycoprotein in the cell host, suggesting oxidative stress from SARSCoV-2 infection, which then produces antibodies (Figure 1). ${ }^{29,30}$ The second mechanism is the two-hit hypothesis related to thrombogenesis. The increase of reactive oxygen by endothelial and macrophages downregulates the antioxidant pathway. This phenomenon, along with the first mechanism, contributes to thrombus formation and activation in the coagulation cascade. ${ }^{31}$

\section{Hypercoagulable state and role of aPL in COVID- 19-positive AIS patients}

The imbalance between procoagulant and anticoagulant can result in a hypercoagulable state. ${ }^{33}$ It can result from various causes, including an inherited or an acquired one. The most common cause of contracted hypercoagulable state is an aPL syndrome which one of the criteria is the presence of aPL antibodies. ${ }^{34,35}$ To initiate a clinical event, aPL antibodies

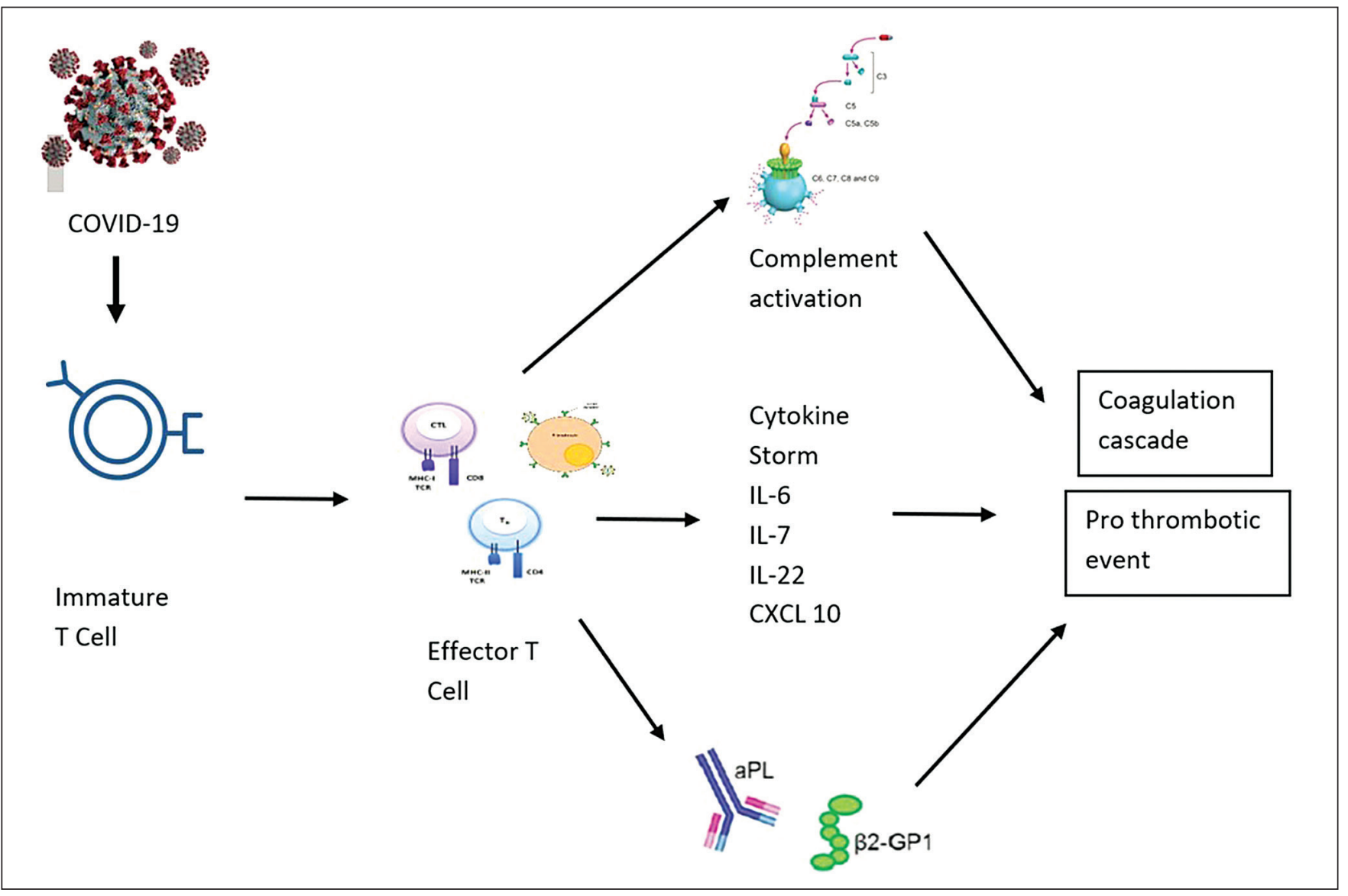

Figure 1. Supporting mechanism of COVID-19 trigger antiphospholipid antibody. There are two hypotheses of aPL and $\beta 2$ glycoprotein 1 production. Molecular mimicry from SARS-CoV-2 and respiratory epithelium invasion, which results in endothelial damage, triggers the effector $\mathrm{T}$ cell to produce the antibody. This process also increases the complement activation and cytokine release, such as cytokine storm syndrome. All of these cascades promote platelet aggregation and increase thrombin generation. ${ }^{32}$ 
Table 1. AIS in COVID-19 case reports and reported aPL findings

\begin{tabular}{|c|c|c|c|c|c|c|c|}
\hline Author, Year & Design & Population & $\begin{array}{c}\text { Number of } \\
\text { Patients with } \\
\text { positive mortality }\end{array}$ & $\begin{array}{l}\text { Laboratory and } \\
\text { CT Findings }\end{array}$ & $\begin{array}{l}\text { NIHSS } \\
\text { (admission, } \\
\text { discharge) }\end{array}$ & $\begin{array}{l}\text { aPL Antibody } \\
\text { Detection }\end{array}$ & Comment \\
\hline $\begin{array}{l}\text { Beyrouti et al. } \\
(2020)\end{array}$ & $\begin{array}{l}\text { Case } \\
\text { Report }\end{array}$ & $\begin{array}{l}\text { Patients with AIS and } \\
\text { COVID-19 (confirmed } \\
\text { by RT PCR). Assessed } \\
\text { between } 1^{\text {st }} \text { and } \\
16^{\text {th }} \text { April } 2020 \text { in } \\
\text { The National Hospital } \\
\text { for Neurology and } \\
\text { Neurosurgery, Queen } \\
\text { Square, London, UK. }\end{array}$ & 1 & $\begin{array}{l}\text { All patients were } \\
\text { either tested } \\
\text { with MRI or } \\
\text { non-contrast- } \\
\mathrm{CT} \text {, and all } \\
\text { showed cerebral } \\
\text { infarctions. }\end{array}$ & $\begin{array}{l}\text { Not } \\
\text { stated }\end{array}$ & $\begin{array}{l}\text { All patients were } \\
\text { tested for } \mathrm{aCL} \text { and } \\
\mathrm{aB}_{2} \mathrm{GP} 1 \text {. } \\
5 / 6 \text { patients } \\
\text { tested positive } \\
\text { for } \mathrm{LAC} \text {. } \\
\text { One patient tested } \\
\text { positive for IgM } \\
\mathrm{aCL} \text { and IgG, IgM } \\
\mathrm{aB}_{2} \mathrm{GP1}\end{array}$ & $\begin{array}{l}\text { The aPL may } \\
\text { be related to } \\
\text { the severity of } \\
\text { the disease }\end{array}$ \\
\hline $\begin{array}{l}\text { Goldberg et } \\
\text { al. (2020) }\end{array}$ & $\begin{array}{l}\text { Case } \\
\text { Report }\end{array}$ & $\begin{array}{l}\text { 64-year-old male } \\
\text { admitted because } \\
\text { of hemiparesis and } \\
\text { shortness of breath. } \\
\text { Sixteen days before } \\
\text { admission patient } \\
\text { was tested positive } \\
\text { for SARS-CoV-2 } \\
\text { infection. }\end{array}$ & 1 & $\begin{array}{l}\text { Elevated } \\
\text { prothrombin time, } \\
\text { D-dimer level, } \\
\text { and ferritin level. } \\
\text { Head CT showed } \\
\text { ischemia }\end{array}$ & $\begin{array}{l}\text { Not } \\
\text { stated }\end{array}$ & aCL IgM positive & $\begin{array}{l}\text { The presence of an } \\
\text { aPL may be related } \\
\text { to an increase in } \\
\text { odds of mortality } \\
\text { in a stroke patient } \\
\text { with COVID-19 }\end{array}$ \\
\hline $\begin{array}{l}\text { Zayet et al., } \\
2020\end{array}$ & $\begin{array}{l}\text { Case } \\
\text { report }\end{array}$ & $\begin{array}{l}\text { Patient with } \\
\text { presumed thrombotic } \\
\text { stroke during } \\
\text { the pandemic of } \\
\text { COVID-19 }\end{array}$ & 1 & $\begin{array}{l}\text { All head CT show } \\
\text { multiple cerebral } \\
\text { infarctions. }\end{array}$ & $\begin{array}{l}\text { Not } \\
\text { stated }\end{array}$ & $\begin{array}{l}1 \text { of } 2 \text { patients } \\
\text { tested positive } \\
\text { for } \mathrm{aCL} \text { IgM }\end{array}$ & $\begin{array}{l}\text { The presence } \\
\text { of an aPL may } \\
\text { be a predictor } \\
\text { of mortality in a } \\
\text { patient stroke with } \\
\text { COVID-19 }\end{array}$ \\
\hline $\begin{array}{l}\text { Zhang et al. } \\
(2020)\end{array}$ & $\begin{array}{l}\text { Case } \\
\text { Series }\end{array}$ & $\begin{array}{l}\text { 69-year-old male, } \\
65 \text {-year-old female, } \\
\text { and } 70 \text {-year-old male } \\
\text { with confirmed SARS- } \\
\text { CoV-2 infection also } \\
\text { developed cerebral } \\
\text { infarctions. }\end{array}$ & $\begin{array}{l}\text { Not } \\
\text { stated }\end{array}$ & $\begin{array}{l}\text { All patients have } \\
\text { elevated D-dimer } \\
\text { and CRP levels; } \\
\text { one patient } \\
\text { has elevated } \\
\text { ferritin levels. } \\
\text { All head CT show } \\
\text { multiple cerebral } \\
\text { infarctions. }\end{array}$ & $\begin{array}{l}\text { Not } \\
\text { stated }\end{array}$ & $\begin{array}{l}\text { All cases tested } \\
\text { positive for } \mathrm{aCL} \\
\operatorname{lgA}, \mathrm{aB}_{2} \mathrm{GP} 1 \mathrm{IgA} \text {, } \\
\text { and } \operatorname{lgG}\end{array}$ & $\begin{array}{l}\text { The presence of } \\
\text { aPL may lead to } \\
\text { poor morbidity }\end{array}$ \\
\hline $\begin{array}{l}\text { Deliwala et al. } \\
\text { (2020) }\end{array}$ & $\begin{array}{l}\text { Case } \\
\text { Report }\end{array}$ & $\begin{array}{l}\text { A 31-year-old female } \\
\text { developed a cerebral } \\
\text { infarction after eight } \\
\text { days admitted with } \\
\text { respiratory symptoms } \\
\text { and confirmed SARS- } \\
\text { CoV-2 infection. }\end{array}$ & 0 & $\begin{array}{l}\text { Elevated Ferritin, } \\
\text { CRP, and } \\
\text { D-dimer level. } \\
\text { Head CT } \\
\text { shows cerebral } \\
\text { infarctions. }\end{array}$ & $\begin{array}{l}\text { Not } \\
\text { stated }\end{array}$ & $\begin{array}{l}\text { Tested negative } \\
\text { for } L A C \text { and } \lg G \\
\text { lgM aCL }\end{array}$ & $\begin{array}{l}\text { The presence of an } \\
\text { aPL may be related } \\
\text { to severe morbidity } \\
\text { in patient stroke } \\
\text { with COVID-19 }\end{array}$ \\
\hline $\begin{array}{l}\text { Viguier A et } \\
\text { al. }(2020)\end{array}$ & $\begin{array}{l}\text { Case } \\
\text { Report }\end{array}$ & $\begin{array}{l}\text { A } 73 \text {-year-old } \\
\text { patient developed } \\
\text { an AIS a week after } \\
\text { respiratory symptoms } \\
\text { related to SARS- } \\
\text { CoV-2 infection. }\end{array}$ & 0 & $\begin{array}{l}\text { Elevated Ferritin, } \\
\text { CRP, and D-dimer }\end{array}$ & 10,3 & $\begin{array}{l}\text { Negative (not } \\
\text { explicitly stated) }\end{array}$ & $\begin{array}{l}\text { Case Report } \\
\text { weighs more about } \\
\text { COVID and Stroke. } \\
\text { aPL only tested for } \\
\text { screening. }\end{array}$ \\
\hline $\begin{array}{l}\text { Gunasekaran } \\
\text { et al. (2020) }\end{array}$ & $\begin{array}{l}\text { Case } \\
\text { Report }\end{array}$ & $\begin{array}{l}\text { A } 40 \text {-year-old female } \\
\text { came to ER with } \\
\text { respiratory symptoms } \\
\text { and tested positive } \\
\text { for SARS-CoV-2 } \\
\text { infection. Seven days } \\
\text { after being admitted } \\
\text { patient developed } \\
\text { cerebral infarctions. }\end{array}$ & 0 & $\begin{array}{l}\text { Elevated ferritin } \\
\text { level. Head CT } \\
\text { showed cerebral } \\
\text { infarctions. }\end{array}$ & $\begin{array}{l}\text { Not } \\
\text { stated }\end{array}$ & LAC negative & $\begin{array}{l}\text { The presence of } \\
\text { an aPL antibody } \\
\text { may be related to } \\
\text { severe morbidity in } \\
\text { patient stroke with } \\
\text { COVID-19 }\end{array}$ \\
\hline
\end{tabular}

Abbreviations: AIS - acute ischemic stroke; $a B_{2} G P 1$ - anti- $B_{2}$-glycoprotein-1; aCL - anticardiolipin; aPL antibodies - antiphospholipid antibodies; LAC - lupus anticoagulant; NIHSS - National Institutes of Health Stroke Scale 
activate cells via several pathways, including the activation of platelets and the complement system. ${ }^{33}$ The thrombotic mechanism involves activating endothelial cells, monocytes, platelet, coagulation factor, and complement proteins. ${ }^{36}$

Though the mechanism is uncertain, some studies describe the unique hypercoagulable state caused by aPL antibodies. It can strike almost every vessel, artery and vein, large vessel, and microcirculation and interfere with the various coagulation process mechanism..$^{35}$

One of the pathogenesis of thrombosis can be explained by the "two-hit" model. The first hit is the presence of aPL antibodies, provided by conditions that can alter the vascular endothelium and increase oxidative stress, such as infection. The first hit or the antibody will induce a thrombophilic state. The second hit is the triggering risk factor which facilitates thrombus formation. These thrombotic events only occur when there is a persistent presence of aPL antibodies. ${ }^{37-39}$

Infectious agents have been proposed as a possible trigger because of the molecular mimicry mechanism. ${ }^{40}$ Infection could initiate an inflammatory response as a part of innate immunity. aPL antibodies could transiently appear in patients with various infections or critically ill patients. Those appearances of antibodies could lead to thrombotic events. ${ }^{41}$

The hypercoagulable state has been observed in COVID-19 patients. Data from several studies found that COVID-19 patients have suffered from coagulation abnormalities, such as elevated von Willebrand factor (vWF), factor VIII, D-dimer, and fibrinogen. ${ }^{42}$

The World Health Organization (WHO) has mentioned that coagulopathy is common in severe COVID-19 infection. Therefore, monitoring of thrombotic events, AIS included, is recommended. ${ }^{43}$ Usually, D-dimer is used as a tool to detect if there was a hypercoagulable state that happened in COVID-19 patients.

Based on the findings above, we suggest that aPL antibodies can be added as an additional tool to detect these events, especially whenever AIS is manifested in COVID-19 patients. Our suggestion is in line with Zhang et al.'s review that proposed aPL antibodies as one of the possible mechanisms that cause hypercoagulability in COVID-19 patients, which eventually cause AIS in COVID-19 patients. ${ }^{44}$

\section{Other possible mechanisms of COVID-19-induced AIS}

Other potential mechanisms have been proposed to explain the occurrence of AIS in COVID-19. We will briefly describe them in the following:

\section{Vasculitis}

As mentioned above, SARS-CoV-2 virus interaction with a human cell is primarily mediated by the ACE2 receptor. Besides lung, this receptor can also be found in vascular endothelium. ${ }^{45}$ SARS-CoV-2 binding to the ACE2 receptor could deplete the amount of endothelial ACE2 and subsequently promote the action of ACE1, a homolog to ACE2. This homolog promotes inflammation and tissue injury in the brain endothelium. ${ }^{46}$ Several cases have been reported regarding this mechanism. Hanafi et al. reported a case of extensive cerebral small-vessel ischemic lesions resembling cerebral vasculitis. ${ }^{47}$ Sousa et al. also reported a case of a 28-years old male who was diagnosed with vasculitis-related stroke. ${ }^{48}$

\section{New-onset atrial fibrillation}

Atrial fibrillation (AF) has been established as a significant risk factor for developing AIS. Framingham's study in 1978 has found AIS incidence in AF patients is five times higher than in non-AF patients. ${ }^{49}$ Several recent reports from other studies mentioned $\mathrm{AF}$ occurrence in COVID-19 patients. Gawalko et al. stated that AF was found in 19 to $21 \%$ of COVID-19 patients. They noted that reliable data for newly diagnosed AF was scarce. Based on current data, they estimated the prevalence of newly diagnosed AF in COVID-19 patients was between 3.6\% and $6.7 \%$. There are several hypotheses proposed to explain this finding, which includes cytokine storm, endothelial dysfunction, electrolyte imbalance, and hypoxemia, all of which leads to a prothrombotic state and eventually make a person susceptible to $\mathrm{AF}^{50}$

\section{Direct viral infection}

A study from Merkler showed that COVID-19 patients have a higher risk of experiencing AIS than influenza patients. ${ }^{51}$ This finding is in line with past finding that influenza-like viral infection could slightly increase the risk of developing AIS. However, the exact mechanism of how SARS-CoV-2 directly causes AIS is still unknown. ${ }^{8}$

\section{SUMMARY}

COVID-19 can manifest itself as a cerebrovascular accident (CVA), mostly AIS. Several studies reported this occurrence. It is suspected that AIS in COVID-19 patient may be caused by aPL that increases when SARS-CoV-2 infect a human body. This may lead to a hypercoagulable state in the blood vessel, which eventually causes thrombosis in the vasculature; in this context, brain vasculature leading to AIS. Some studies noted the presence of aPL in COVID-19 patients who had AIS.

A more comprehensive study is warranted to establish this correlation and explore whether these findings can be helpful in a clinical setting, whether as an additional tool for examination or as a target for therapy.

\section{Statement of Authorship}

All authors participated in the data collection and analysis, and approved the final version submitted.

\section{Author Disclosure}

All authors declared no conflicts of interest. 


\section{Funding Source}

This study has no external funding support.

\section{REFERENCES}

1. Ouassou H, Kharchoufa L, Bouhrim M, Daoudi NE, Imtara H, Bencheikh N, et al. The Pathogenesis of Coronavirus Disease 2019 (COVID-19): Evaluation and Prevention. J Immunol Res. 2020 Jul 10;2020:1357983. doi: 10.1155/2020/1357983. PMID: 32671115; PMCID: PMC7352127.

2. Center for Systems Science and Engineering (CSSE) at JHU. COVID-19 Dashboard [Internet]. 2021 [cited Apr 2021] Available from: https://coronavirus.jhu.edu/map.

3. Trypsteen W, Van Cleemput J, Snippenberg WV, Gerlo S, Vandekerckhove L. On the Whereabouts of SARS-CoV-2 in the Human Body: A Systematic Review. PLoS Pathog. 2020 Oct 30;16(10):e1009037. doi: 10.1371/journal.ppat.1009037. PMID: 33125439; PMCID: PMC7679000.

4. Zuo Y, Estes SK, Ali RA, Gandhi AA, Yalavarthi S, Shi H, et al. Prothrombotic Autoantibodies in Serum from Patients Hospitalized with COVID-19. Sci Transl Med. 2020 Nov 18;12(570):eabd3876. doi: 10.1126/scitranslmed.abd3876. Epub 2020 Nov 2. PMID: 33139519; PMCID: PMC7724273.

5. Amezcua-Guerra LM, Rojas-Velasco G, Brianza-Padilla M, VázquezRangel A, Márquez-Velasco R, Baranda-Tovar F, et al. Presence of Antiphospholipid Antibodies in COVID-19: Case Series Study. Ann Rheum Dis. 2020 Aug 4:annrheumdis-2020-218100. doi: 10.1136/ annrheumdis-2020-218100. Epub ahead of print. PMID: 32753426.

6. Reyes GM, Barouqa M, Szymanski J, Gonzalez-Lugo JD, Rahman S, Billett HH. Assessment of Lupus Anticoagulant Positivity in Patients With Coronavirus Disease 2019 (COVID-19). JAMA Netw Open. 2020 Aug 3;3(8):e2017539. doi: 10.1001/ jamanetworkopen.2020.17539. PMID: 32785632.

7. Fifi JT, Mocco J. COVID-19 Related Stroke in Young Individuals. Lancet Neurol. 2020 Sep;19(9):713-5. doi: 10.1016/S1474-4422(20) 30272-6. PMID: 32822622; PMCID: PMC7434432.

8. Elkhider H, Ibrahim F, Sharma R, Sheng S, Jasti M, Lotia M, et al. COVID-19 and Stroke, a Case Series and Review of Literature. Brain Behav Immun Health. 2020 Dec;9:100172. doi: 10.1016/j. bbih.2020.100172. Epub 2020 Nov 4. PMID: 33173859; PMCID: PMC7641528.

9. Tan YK, Goh C, Leow AST, Tambyah PA, Ang A, Yap ES, et al. COVID-19 and Ischemic Stroke: A Systematic Review and Meta-summary of the Literature. J Thromb Thrombolysis. 2020 Oct;50(3):587-95. doi: 10.1007/s11239-020-02228-y. PMID: 32661757; PMCID: PMC7358286.

10. Nannoni S, de Groot R, Bell S, Markus HS. Stroke in COVID-19: A Systematic Review and Meta-analysis. Int J Stroke. 2021 Feb;16(2):137-49. doi: 10.1177/1747493020972922. Epub 2020 Nov 11. PMID: 33103610; PMCID: PMC7859578.

11. Siow I, Lee KS, Zhang JJY, Saffari SE, Ng A, Young B. Stroke as a Neurological Complication of COVID-19: A Systematic Review and Meta-Analysis of Incidence, Outcomes and Predictors. J Stroke Cerebrovasc Dis. 2021 Mar;30(3):105549. doi: 10.1016/j. jstrokecerebrovasdis.2020.105549. Epub 2020 Dec 15. PMID: 33341565; PMCID: PMC7834121.

12. Bekelis K, Missios S, Ahmad J, Labropoulos N, Schirmer CM, Calnan DR, et al. Ischemic Stroke Occurs Less Frequently in Patients With COVID-19: A Multicenter Cross-Sectional Study. Stroke. 2020 Dec;51(12):3570-3576. doi: 10.1161/STROKEAHA.120.031217. Epub 2020 Oct 27. PMID: 33106109; PMCID: PMC7678670.

13. Misita CP, Moll S. Antiphospholipid Antibodies. Circulation. 2005 Jul 19;112(3):e39-44. doi: 10.1161/CIRCULATIONAHA. 105.548495. PMID: 16027261.

14. Gonzales-Portillo F, McIntyre JA, Wagenknecht DR, Williams LS, Bruno A, Biller J. Spectrum of Antiphospholipid Antibodies (aPL) in Patients with Cerebrovascular Disease. J Stroke Cerebrovasc Dis.
2001 Sep-Oct;10(5):222-6. doi: 10.1053/jscd.2001.29818. PMID: 17903828.

15. McIntyre JA, Wagenknecht DR, Faulk WP. Antiphospholipid Antibodies: Discovery, Definitions, Detection and Disease. Progress in Lipid Research. 2003. 42(3), 176-237. doi:10.1016/s01637827(02)00048-6

16. Shoenfeld Y, Twig G, Katz U, Sherer Y. Autoantibody Explosion in Antiphospholipid Syndrome. Journal of Autoimmunity. 2008. 30(1-2), 74-83. doi:10.1016/j.jaut.2007.11.011

17. de Laat HB, Derksen RH, Urbanus RT, Roest M, de Groot PG. Beta2glycoprotein I-dependent Lupus Anticoagulant Highly Correlates with Thrombosis in the Antiphospholipid Syndrome. Blood. 2004 Dec 1;104(12):3598-602. doi: 10.1182/blood-2004-03-1107. Epub 2004 Aug 17. PMID: 15315975.

18. Sène D, Piette JC, Cacoub P. Antiphospholipid Antibodies, Antiphospholipid Syndrome and Infections. Autoimmun Rev. 2008 Feb;7(4):272-7. doi: 10.1016/j.autrev.2007.10.001. Epub 2007 Oct 23. PMID: 18295729 .

19. de Groot PG, Urbanus RT, Derksen RH. Pathophysiology of Thrombotic APS: Where Do We Stand? Lupus. 2012 Jun;21(7): 704-7. doi: 10.1177/0961203312438631. PMID: 22635207.

20. Radic M, Pattanaik D. Cellular and Molecular Mechanisms of Anti-Phospholipid Syndrome. Front Immunol. 2018 May 7;9:969. doi: 10.3389/fimmu.2018.00969. PMID: 29867951; PMCID: PMC5949565.

21. Beyrouti R, Adams ME, Benjamin L, Cohen H, Farmer SF, Goh YY, et al. Characteristics of Ischaemic Stroke Associated with COVID-19. J Neurol Neurosurg Psychiatry. 2020 Aug;91(8):889-91. doi: 10.1136/jnnp-2020-323586. Epub 2020 Apr 30. PMID: 32354768; PMCID: PMC7231545.

22. Goldberg MF, Goldberg MF, Cerejo R, Tayal AH. Cerebrovascular Disease in COVID-19. AJNR Am J Neuroradiol. 2020 Jul;41(7):1170 1172. doi: 10.3174/ajnr.A6588. Epub 2020 May 14. PMID: 32409316; PMCID: PMC7357639.

23. Zayet S, Klopfenstein T, Kovảcs R, Stancescu S, Hagenkötter B. Acute Cerebral Stroke with Multiple Infarctions and COVID-19, France, 2020. Emerg Infect Dis. 2020 Sep;26(9):2258-60. doi: 10.3201/eid2609.201791. Epub 2020 May 26. PMID: 32453685; PMCID: PMC7454094.

24. Zhang Y, Xiao M, Zhang S, Xia P, Cao W, Jiang W, et al. Coagulopathy and Antiphospholipid Antibodies in Patients with Covid-19. N Engl J Med. 2020 Apr 23;382(17):e38. doi: 10.1056/NEJMc2007575. Epub 2020 Apr 8. PMID: 32268022; PMCID: PMC7161262.

25. Deliwala S, Abdulhamid S, Abusalih MF, Al-Qasmi MM, Bachuwa G Encephalopathy as the Sentinel Sign of a Cortical Stroke in a Patient Infected With Coronavirus Disease-19 (COVID-19). Cureus. 2020 May 14;12(5):e8121. doi: 10.7759/cureus.8121. PMID: 32426200; PMCID: PMC7228791.

26. Viguier A, Delamarre L, Duplantier J, Olivot JM, Bonneville F. Acute Ischemic Stroke Complicating Common Carotid Artery Thrombosis during a Severe COVID-19 Infection. J Neuroradiol. 2020 Sep;47(5):393-4. doi: 10.1016/j.neurad.2020.04.003. Epub 2020 May 4. PMID: 32389423; PMCID: PMC7196531.

27. Gunasekaran K, Amoah K, Rajasurya V, Buscher MG. Stroke in a Young COVID-19 Patient. QJM. 2020 Aug 1;113(8):573-4. doi 10.1093/qjmed/hcaa177. PMID: 32442268; PMCID: PMC7313834.

28. Kwah LK, Diong J. National Institutes of Health Stroke Scale (NIHSS). J Physiother. 2014 Mar;60(1):61. doi: 10.1016/j.jphys. 2013.12.012. Epub 2014 May 3. PMID: 24856948.

29. Ouassou H, Kharchoufa L, Bouhrim M, Daoudi NE, Imtara H, Bencheikh N, et al. The Pathogenesis of Coronavirus Disease 2019 (COVID-19): Evaluation and Prevention. J Immunol Res. 2020 Jul 10;2020:1357983. doi: 10.1155/2020/1357983. PMID: 32671115; PMCID: PMC7352127.

30. Delgado-Roche L, Mesta F. Oxidative Stress as Key Player in Severe Acute Respiratory Syndrome Coronavirus (SARS-CoV) Infection. Arch Med Res. 2020 Jul;51(5):384-7. doi: 10.1016/j. arcmed.2020.04.019. Epub 2020 Apr 30. PMID: 32402576; PMCID: PMC7190501. 
31. Fischetti F, Durigutto P, Pellis V, Debeus A, Macor P, Bulla R, et al. Thrombus Formation Induced by Antibodies to Beta2-glycoprotein I is Complement Dependent and Requires a Priming Factor. Blood. 2005 Oct 1;106(7):2340-6. doi: 10.1182/blood-2005-03-1319. Epub 2005 Jun 14. PMID: 15956288.

32. Tung ML, Tan B, Cherian R, Chandra B. Anti-phospholipid Syndrome and COVID-19 Thrombosis: Connecting the Dots. Rheumatol Adv Pract. 2021 Feb 4;5(1):rkaa081. doi: 10.1093/rap/ rkaa081. PMID: 33615129; PMCID: PMC7882149.

33. Salmon JE, de Groot PG. Pathogenic Role of Antiphospholipid Antibodies. Lupus. 2008 May;17(5):405-11. doi: 10.1177/ 0961203308090025. PMID: 18490417; PMCID: PMC2693020.

34. Nakashima MO, Rogers HJ. Hypercoagulable States: An Algorithmic Approach to Laboratory Testing and Update on Monitoring of Direct Oral Anticoagulants. Blood Res. 2014 Jun;49(2):85-94. doi: 10.5045/br.2014.49.2.85. Epub 2014 Jun 25. PMID: 25025009; PMCID: PMC4090343.

35. Tortosa C, Cabrera-Marante O, Serrano M, Martínez-Flores JA, Pérez D, Lora D, et al. Incidence of Thromboembolic Events in Asymptomatic Carriers of IgA Anti 32 Glycoprotein-I Antibodies. PLoS One. 2017 Jul 20;12(7):e0178889. doi: 10.1371/journal. pone.0178889. PMID: 28727732; PMCID: PMC5519006.

36. Zuo Y, Shi H, Li C, Knight JS. Antiphospholipid Syndrome: A Clinical Perspective. Chin Med J (Engl). 2020 Apr 20;133(8):92940. doi: 10.1097/CM9.0000000000000705. PMID: 32265421; PMCID: PMC7176446.

37. Linnemann B. Antiphospholipid Syndrome - An Update. Vasa. 2018 Oct;47(6):451-64. doi: 10.1024/0301-1526/a000723. Epub 2018 Sep 12. PMID: 30205764.

38. Xie H, Sheng L, Zhou H, Yan J. The Role of TLR4 in Pathophysiology of Antiphospholipid syndrome-associated Thrombosis and Pregnancy Morbidity. Br J Haematol. 2014 Jan;164(2):165-76. doi: 10.1111/ bjh.12587. Epub 2013 Oct 8. PMID: 24180619.

39. Meroni PL, Raschi E, Grossi C, Pregnolato F, Trespidi L, Acaia B, et al. Obstetric and Vascular APS: Same Autoantibodies But Different Diseases? Lupus. 2012 Jun;21(7):708-10. doi: 10.1177/ 0961203312438116. PMID: 22635208.

40. Abdel-Wahab N, Lopez-Olivo MA, Pinto-Patarroyo GP, SuarezAlmazor ME. Systematic Review of Case Reports of Antiphospholipid Syndrome Following Infection. Lupus. 2016 Dec;25(14):1520-31. doi: 10.1177/0961203316640912. Epub 2016 Apr 7. PMID: 27060064; PMCID: PMC7508159.

41. Zhang Y, Xiao M, Zhang S, Xia P, Cao W, Jiang W, et al. Coagulopathy and Antiphospholipid Antibodies in Patients with Covid-19. N Engl J Med. 2020 Apr 23;382(17):e38. doi: 10.1056/NEJMc2007575. Epub 2020 Apr 8. PMID: 32268022; PMCID: PMC7161262.
42. Ranucci M, Ballotta A, Di Dedda U, Bayshnikova E, Dei Poli M, Resta M, et al. The Procoagulant Pattern of Patients with COVID-19 Acute Respiratory Distress Syndrome. J Thromb Haemost. 2020 Jul;18(7):1747-51. doi: 10.1111/jth.14854. Epub 2020 May 6. PMID: 32302448.

43. World Health Organization. 2021. COVID-19 Clinical Management Living Guidance [Internet].2021 [cited May 2021]. Available from https://www.who.int/publications/i/item/WHO-2019-nCoVclinical-2021-1.

44. Zhang S, Zhang J, Wang C, Chen X, Zhao X, Jing H, et al. COVID-19 and Ischemic Stroke: Mechanisms of Hypercoagulability (Review). Int J Mol Med. 2021 Mar;47(3):21. doi: 10.3892/ijmm.2021.4854. Epub 2021 Jan 15. PMID: 33448315; PMCID: PMC7849983.

45. Spence JD, de Freitas GR, Pettigrew LC, Ay H, Liebeskind DS, Kase CS, et al. Mechanisms of Stroke in COVID-19. Cerebrovasc Dis. 2020;49(4):451-8. doi: 10.1159/000509581. Epub 2020 Jul 20. PMID: 32690850; PMCID: PMC7445374.

46. Hess DC, Eldahshan W, Rutkowski E. COVID-19-Related Stroke. Transl Stroke Res. 2020 Jun;11(3):322-5. doi: 10.1007/s12975020-00818-9. Epub 2020 May 7. PMID: 32378030; PMCID: PMC7202903.

47. Hanafi R, Roger PA, Perin B, Kuchcinski G, Deleval N, Dallery F, et al. COVID-19 Neurologic Complication with CNS VasculitisLike Pattern. AJNR Am J Neuroradiol. 2020 Aug;41(8):1384-7. doi: 10.3174/ajnr.A6651. Epub 2020 Jun 18. PMID: 32554425; PMCID: PMC7658880.

48. de Sousa GC, de Sousa TC, Sakiyama MAK, da Silva JSNL, de Sousa EJS. Vasculitis-related Stroke in Young as a Presenting Feature of Novel Coronavirus Disease (COVID19) - Case Report. J Clin Neurosci. 2020 Sep;79:169-71. doi: 10.1016/j.jocn.2020.07.034. Epub 2020 Jul 17. PMID: 33070890; PMCID: PMC7367000.

49. Wolf PA, Dawber TR, Thomas HE Jr., Kannel WB. Epidemiologic Assessment of Chronic Atrial Fibrillation and Risk of Stroke: The Framingham Study. Neurology Oct 1978, 28 (10) 973; DOI: 10.1212/ WNL.28.10.973

50. Gawałko M, Kapłon-Cieślicka A, Hohl M, Dobrev D, Linz D. COVID-19 Associated Atrial Fibrillation: Incidence, Putative Mechanisms and Potential Clinical Implications. Int J Cardiol Heart Vasc. 2020 Oct;30:100631. doi:10.1016/j.ijcha.2020.100631. Epub 2020 Sep 1. PMID: 32904969; PMCID: PMC7462635

51. Merkler AE, Parikh NS, Mir S, Gupta A, Kamel H, Lin E, et al. Risk of Ischemic Stroke in Patients With Coronavirus Disease 2019 (COVID-19) vs. Patients With Influenza. JAMA Neurol. 2020 Jul 2;77(11):1-7. doi: 10.1001/jamaneurol.2020.2730. Epub ahead of print. PMID: 32614385; PMCID: PMC7333175.

\section{The Acta Medica Philippina is now accepting limited advertising for its front and back cover (colored), as well as for available spaces in some of its pages, as appropriate. For inquiries and submission of proposals, please email us at actamedicaphilippina.upm@up.edu.ph}

